\title{
Aliansi Negara Komunis dan Fundamentalis Agama dalam Melindungi Posisi Nicolas Maduro dari Tekanan Politik Internasional Negara Barat
}

\author{
Bagus Subekti Nuswantoro \\ Program Studi Ilmu Hubungan Internasional, Universitas Respati Yogyakarta - Indonesia \\ Email: bagus.subekti07@gmail.com \\ Diserahkan: 30 Desember 2019| Diterima: 30 Juni 2020
}

\begin{abstract}
This paper seeks to provide a view that international relations after the Cold War remains dominated by the interests of superpowers such as the United States, China and Russia. This can be seen from the behavior of these countries in influencing Venezuela. On the other hand, Turkey as a country with an Islamic Fundamentalist character under Erdogan's leadership was involved in the struggle for influence in Venezuela. What's interesting is that in this condition Turkey was in the ranks of China and Russia to support the Nicolas Maduro Government. The aim of this study is to look at the efforts of the Communist ideology (Russian) and Islamic Fundamentalism (Turkey) state in defending Nicolas Maduro's position as president of Venezuela from Western pressure.
\end{abstract}

Keyword: Power, Alliance, Communist, Fundamentalist.

\begin{abstract}
Abstrak
Tulisan ini berusaha memberikan pandangan bahwa hubungan internasional paska perang dingin tetap didominasi oleh kepentingan Negara-negara adidaya seperti Amerikda, Cina dan Rusia. Hal tersebut terlihat dari perilaku Negara-negara tersebut dalam memberikan pengaruh di Venezuela. Di sisi lain, Turki sebagai Negara dengan karakter Fundamentalis Islam di bawah kepemimpinan Erdogan ikut terlibat perebutan pengaruh di Venezuela. Yang menarik adalah pada kondisi ini turki berada di barisan Cina dan Rusia untuk mendukung Pemerintahan Nicolas Maduro. Tujuan dari penelitian ini adalah untuk melihat upaya dari Negara berideologi Komunis (Rusia) dan Fundamentalisme Islam (Turki) dalam mempertahankan posisi Nicolas Maduro sebagai presiden Venezuela dari tekanan negara Barat.
\end{abstract}

Kata Kunci: Kekuatan, Aliansi, Komunis, Fundamentalis.

\section{PENDAHULUAN}

Berakhirnya Perang Dingin telah menjadi akhir dari sistem dunia Bipolar Amerika versus Uni Soviet. Berakhirnya Perang Dingin telah menginspirasi Huntington untuk mengemukakan pendapatnya tentang akhir dari sebuah pola rivalitas negara dan akan kembali kepada rivalitas tradisional (Vitria, 2009). Tulisan yang berjudul The Clash of Civilizations and The Remarking of
World Order berusaha memprediksi pola hubungan internasional setelah Perang Dingin untuk kembali lagi kepada bentuk sistem multipolar yang menjadi karakteristik hubungan internasional era 1945-an (Yuniarti, 2010). Pergeseran pola hubungan internasional ini menarik perhatian penulis untuk menganalisa pola baru dari aliansi kekuatan yang tercipta 
pasca peristiwa 9/11

Pasca Perang Dingin menjadi era baru hubungan internasional sekaligus memperkenalkan pemeran baru dalam politik internasional, yaitu Barat versus Islam. Hal ini dipengaruhi oleh kebangkitan Islam dan pandangan mereka di pemerintahan dan di media yang mengangkat spectrum ancaman religious, politik, budaya dan demografi fundamentalisme Islam yang muncul dari negara-negara Islam di Timur Tengah (John L.Esposito, 2010).

Dua fase peradaban yang berbeda sejatinya memiliki beberapa kemiripan, di antaranya adalah keduanya samasama diperankan oleh barat (Amerika dan sekutunya) melawan negara komunis dan negara fundamentalis agama. Meminjan konsep yang digunakan oleh aliansi negara barat dengan Uni Soviet dalam upaya melawan agresifitas Nazi yaitu "the enemy of my enemy is my friend" maka mungkinkah negara Komunis dan negara fundamentalis agama menjadi satu aliansi untuk melawan Amerika dan sekutunya dalam politik internasional?.

Krisis ekonomi dan politik Venezuela pada September 2018 lalu menyebabkan banyak permasalahan baik domestik maupun internasional. Kondisi demikian mengancam posisi Nicolas Maduro sebagai Presiden Venezuela dengan lahirnya kekuatan oposisi yang dipimpin oleh Juan Guaido yang mengangkat dirinya sendiri sebagai presiden sementara di Venezuela.

Dinamika yang terjadi di Venezuela tersebut menjadi menarik setelah Presiden AS Donald Trump menyatakan dukungannya kepada pimpinan oposisi tersebut sebagai presiden sementara Venezuela (Trump, 2019). Menjadi semakin menarik lagi setelah China, Rusia dan Turki menyatakan dukungannya kepada Presiden Nicolas Maduro (Riza, 2019). Sehingga kita melihat bahwa negara komunis dan negara dengan basis Islam berada dalam satu barisan politik. Maka dapatkah fenomena ini kita sebut sebagai aliansi antara negara komunis dan negara fundementalis Islam?.

Penulis menemukan beberapa tulisan tentang Venezuela namun sebagian besar hanya berfokus terhadap konflik antara pemerintah dan kelompok oposisi. Penulis juga menemukan beberapa tulisan yang menjelaskan tentang hubungan antara China dan Rusia sebagai sekutu negara Komunis namun penulis belum melihat hubungan antara negara yang berbasis pada ideologi komunis dengan negara yang berbasis Islam, karena pada dasarnya kedua ideologi tersebut jelas sangat bertentangan. 
Inilah mengapa penulis merasa tertantang untuk menemukan jawaban atas fenomena yang terjadi di Venezuela.

Artikel ini berusaha membuka fakta tentang kebijakan dari masingmasing negara untuk dapat melihat motif dari dukungannnya terhadap Nicolas Maduro. Selain itu penulis juga tertarik untuk menemukan kemiripan pola yang terjadi pada Venezuela sebagai pemicu terjadinya hubungan yang terjalin atas musuh bersama seperti yang terjadi pada saat Perang Dunia II.

Tulisan ini bertujuan untuk menganalisa bagaimana pola hubungan internasional antara negara komunis dan negara Islam yang didasari oleh fenomena krisis Venezuela dapat membentuk pola aliansi seperti yang terjadi pada Perang Dunia II. Selain itu tulisan ini juga berusaha membuktikan bahwa sistem dunia Multipolar masih sangat relevan meskipun Amerika diklaim menjadi pemenang Perang Dingin. Terakhir, penulis ingin membuktikan bahwa ramalan dari tulisan Huntington "The Clash of Civilizations and The Remarking of World Order" yang akhirnya menghadirkan aktor baru dalam hubungan internasional seperti kelompok teroris belum bisa menghapuskan revelansi negara sebagai aktor utama dalam hubungan internasional.
Tulisan ini berfokus pada pola hubungan antar negara komunis dan negara Islam dalam kasus krisis ekonomi dan politik yang terjadi di Venezuela, namun tulisan ini tidak bertujuan untuk menjelaskan secara mendalam fenomena krisis termasuk yang terjadi di Venezuela. Tulisan ini juga tidak banyak membahas tentang kebijakan luar negeri Amerika dalam mendukung kelompok oposisi yang dipimpin oleh Juan Guaido.

\section{KERANGKA PEMIKIRAN}

Untuk melengkapi tinjauan pustaka pada tulisan ini penulis memilih beberapa tulisan terkait yang pernah dibuat sebelumnya. Salah yang yang menarik perhatian penulis adalah tulisan milik Yuniarti yang menjelaskan pola hubungan internasional abad ke 20 dan pengaruhnya terhadap Realisme versus Idealisme. Tulisan tersebut menceritakan tentang pergeseran pola hubungan internasional yang dipengaruhi oleh beberapa hal diantaranya: berakhirnya Perang Dingin, runtuhnya kekuatan Uni Soviet, meningkatnya interdependensi ekonomi dan meluasnya paham demokrasi. Yuniarti menjelaskan bahwa keempat hal tersebut berpotensi dapat mempengaruhi perubahan pola hubungan internasional dan terhadap teori hubungan internasional dari kelompok 
Realisme dan Liberalisme.

Meskipun nilai-nilai liberalisme lebih mendominasi dalam pergeseran pola hubungan internasional yang ada, namun sejatinya pandangan realisme tidak benar-benar bisa dihapuskan dari fenomena internasional. Hal ini terlihat pada cara-cara menuju perdamaian yaitu balance of power, aliansi dan concern of power (Yuniarti, 2010). Dari sini penulis melihat bahwa Yuniarti hanya berfokus pada komparasi dominasi Realisme dan Liberalisme dalam menjelaskan fenomena internasional secara general dan kurang fokus terhadap satu masalah tertentu. Untuk memudahkan dalam pembahasan maka penulis memilih beberapa teori dan konsep yang relevan dengan kasus ini.

\section{Concern of Power}

Untuk menganalisa kasus ini penulis menggunakan teori Concern of Power. Dalam tulisan Yuniarti dijelaskan bahwa ini merupakan sistem keamanan yang dijaga oleh negaranegara besar seperti negara-negara Eropa Barat dan AS yang bekerja sama dengan negara-negara sekutu kondisionalnya, dengan kesepakatankesepakatan tertentu (Yuniarti, 2010). Concern of Power pada akhirnya menciptakan perimbangan kekuasaan dalam batasan keseimbangan dalam posisi tawar-menawar dalam suatu negosiasi atau perundingan damai, seperti yang terjadi di Eropa sekitar abad 19. Concern of Power bersifat longgar dan tidak permanen sehingga aliansi yang terbentuk bisa berubahubah sesuai dengan kebutuhan, kepentingan, atau mutual trade-off di antara kedua pihak (pendukung dan yang didukung). Negara-negara berpotensi menjadi pendukung dalam sistem ini antara lain adalah China, Rusia, dan India.

\section{Alansi}

Aliansi tumbuh sebagai akibat dari munculnya persepsi tentang adanya musuh bersama atau ancaman luar (Dwivedi, 2012). Aliansi adalah suatu perjanjian atau kesepakatan antara dua negara atau lebih untuk saling membantu dalam sebuah kondisi yang telah ditetapkan, biasanya ketika salah satu negara anggota perjanjian tersebut mengalami serangan oleh negara di luar anggota. Sebagian kalangan memandang aliansi memang kecenderungan manusia untuk bersatu dalam menghadapi ancaman (Michael Roskin, 1990).

Stephen M. Walt menambahkan bahwa aliansi itu biasanya muncul sebagai respon dari sebuah ancaman. Ia menjelaskan dalam hal merespon sebuah ancaman, negara yang terlibat dalam aliansi akan menempati dua posisi yaitu balance (allyin opposition to the principal sourceof danger) or bandwagon (ally with the state that poses the major threat). 
Balance lebih banyak ditemui karena ini merupakan respon dengan cara bersatu untuk menghindari agresi dari pihak lain. Sedangkan bandmagon identik sebuah negara yang diktator karena berkumpul untuk menyebarkan ketakutan (Walt, 2015). Sehingga dapat disimpulkan bahwa yang pertama lebih memilih untuk beraliansi dengan yang lebih lemah, sedangkan yang kedua cenderung memilih beraliansi dengan yang lebih kuat.

Namun dua hal di atas bisa juga terjadi sebaliknya. Dalam hal ini Stephen M. Walt juga menjelaskan bahwa terdapat kemungkinan balance terjadi di mana negara yang lebih kuat beraliansi dengan negara yang kuat juga dikarenakan negera yang lebih lemah tadi lebih berbahasa atas alasan tertentu. Seperti apa yang terjadi di Perang Dunia I dan II di mana negara besar bersatu untuk menghadapi Jerman yang dianggap sangat membahayakan bagi dunia.

Dari sini kita dapat melihat bahwa negara komunis dan negara Islam melihat suatu ancaman yang mendorong mereka bersatu dalam menentang Amerika yang mendukung kelompok oposisi di Venezuela.

\section{ANALISIS DAN PEMBAHASAN}

Posisi Nicolas Maduro tidak pernah aman dari tekanan politik internasional negara barat terutama
Amerika Serikat. Segala upaya dilakukan Amerika untuk mengacaukan stabilitas politik, sosial dan ekonomi guna merebut pengaruh di wilayah Amerika Latin tersebut. Di sisi lain negara pesaing Amerika, seperti Rusia dan China tidak ingin melepaskan begitu saja pengaruh mereka yang notabene sudah lebih dulu tertanam di negara tersebut dengan cara mempertahankan posisi sang pemimpin (Nicolas Maduro) untuk tetap eksis dan mempertahankan status quo. Kehadiran Turki sebagai representasi negara fundamentalis Islam (Rofii, 2019) di bawah pimpinan Recep Tayyip Erdoğan dalam mendukung Nicolas Maduro dari upaya kudeta kelompok oposisi.

Pembahasan kali ini penulis ingin memaparkan hasil penelitian yang akan diuraikan dalam beberapa sub bab diantaranya, pertama penulis akan mengulas kembali bagaimana tekanan Amerika terhadap Presiden Venezuela (Nicoas Maduro) sejak pertama kali terpilih pada tahun 2013 menggantikan seniornya Hugo Cháves (Romero \& Mujares, April 2016) yang berasal dari partai yang sama Partido Socialista Unido de Venezuela (PSUV). Kedua, penulis ingin mengulas kembali secara bistory hubungan antara negara komunis dan Fundamentalis Islam dalam melawan kapitalis. Ketiga, penulis ingin menganalisa bagaimana upaya negara 
komunis dan fundamentalis Islam dalam melindungi posisi Nicolas Maduro dari tekanan politik Amerika.

\section{Tekanan Amerika Terhadap Posisi Nicolas Maduro Sebagai Presiden Venezuela}

Krisis politik dan ekonomi yang mulai terjadi dalam kurun waktu 5 tahun terakhir telah menempatkan Venezuela dalam posisi yang sulit. Tekanan dan kecaman datang dari berbagai negara yang melihat kegagalan Venezuela dalam menerapkan sistem perekonomian sosialisnya. Kegagalan tersebut menyebabkan terjadinya krisis kemanusiaan yang kemudian mengundang reaksi yang keras dari Amerika Serikat. Amerika sendiri memberikan setidaknya dua tekanan berat kepada Venezuela, yaitu tekanan secara bilateral dan melalui pendekatan regional. Tekanan yang pertama (bilateral) berupa sanksi yaitu excutive order 13.692. Sedangkan pada era Donald Trump, terdapat ancaman militer melalui Dewan Keamanan PBB pada 11 Agustus 2017 dan pembaharuan sanksi excutive order 13.692 yang berisikan larangan segala bentuk transaksi dengan pemerintahan Venezuela dan perusahaan minyak Venezuela, Petroleos de Venequela, S.A. (PDVSA). Tekanan kedua (regional), yaitu sejak 2015 Amerika Serikat telah mendesak organisasi regional Organization of American States (OAS) untuk memberikan sanksi yang lebih tegas terhadap pemerintahan Maduro. Sehingga tahun 2016 Sekertaris Jendral OAS Luis Almagro meminta komunitas internasional untuk meningkatkan sanksi kepada pemerintahan Maduro dan meminta Venezuela menandatangani InterAmerica Democratic Charter sebagai dasar dari proses alterasi pengaturan Undang-Undang tentang demokrasi di Venezuela (Firdaus, 2018).

Bentuk tekanan yang lain terlihat dari dukungan Amerika Serikat kepada pemimpin oposisi Juan Guaido yang menyatakan diri sebagai presiden sementara di awal tahun 2019 ini (BBC INDONESIA, 2019). Guaido langsung mendapat dukungan dari 53 negara termasuk negara besar di wilayah Amerika Latin seperti Brazil, Kolombia dan Argentina. Guaido berusaha meraih dukungan dari dua posisi penting di bidang keamanan yaitu polisi dan militer guna menyalurkan bantuan kemanusiaan yang berpusat di perbatasan Colombia, Brazil dan Venezuela, meskipun sempat diblokir oleh pendukung Maduro namun pada akhirnya PBB melalui International Federation of Red Cross and Red Crescent Societies (IFRC) diberi kesempatan untuk menyalurkan bantuannya (Seelke, Brown, M. Nelson, \& Margesson, 2019). Dengan 
itu Guaido berharap agar tekanan internasional dapat mendatangkan pergerakan dibidang militer guna memaksa Maduro lengser dan diselenggarakannya pemilu ulang.

\section{Aliansi Negara Komunis dengan Fundamentalis Agama}

Sejarah tentang rivalitas negara barat (dalam konteks ini Amerika dan sekutunya) telah menghadirkan dua musuh utama pada era yang berbeda yaitu Komunis di era perang dingin dan Islam di era pasca Perang Dingin. Fakta yang unik ini menunjukkan bahwa keduanya memiliki posisi yang sama di mata barat. Islamisme merupakan istilah yang mengacu pada sebuah jenis interpretasi agama, organisasi serta gerakan di kalangan umat islam yang sering juga disebut dengan istilah fundamentalisme atau salafisme (Mudzakkir, 2016).

Tepat setelah tembok Berlin runtuk dan Uni Soviet bubar, sebagian besar orang menyatakan bahwa komunisme sudah mati. Namun beberapa tahun kemudian gerakangerakan menolak neoliberal kapitalisme yang sejatinya sudah ada sejak 1980an kembali mencuat. Di tahun 1994 kelompok EZLN menyatakan perang terhadap pemerintah Meksiko dan korporasikorporasi dunia yang telah menjarah tanah adat di Chiapas. Lima tahun kemudian Hugo

Cháves memenangkan pemilu di Venezuela dan diikuti kandidat sosialis lainnya di Brazil, Argentina, Cile, Bolivia, Ekuador, dan Nikaragua (Jusuf, 2017). Hal tersebut menunjukkan bahwa sebenarnya rivalitas sosialis komunis terhadap kapitalisme (barat) masih berlanjut hingga saat ini.

\section{Sedangkan}

Mudzakir berargumen bahwa di sisi lain Islam dihadapkan dengan modernisasi yang menuntut mereka terjun di dunia politik negara modern. Kaum muslim banyak yang melibatkan diri ke dalam partai politik yang dan gerakan sosial dengan ideologi yang beragam termasuk sosialisme komunisme (Mudzakkir, 2016). Di Indonesia, pada pemilihan umum 1955, partai-partai Islam seperti Masyumi dan Nahdlatul Ulama harus berbagi tempat dengan partai nasionalis dan komunis. Contoh lainnya di Palestina terdapat Front Rakyat untuk Pembebasan Palestina atau Popular Front for the Liberation of Palestine (PFLP), yang merupakan partai berhaluan Marxis-Leninis (kiri) terbesar di sana yang diikuti oleh Democratic Front for The Liberation of Palestine dan Palestinian People Party. PHLP yang didirikan oleh George Habash pada tahun 1967 sangat aktif memperjuangkan kebebasan dan kemerdekaan Palestina dengan melawan Israel, Zionisme dan sekutunya baik melalui perlawanan bersenjata ataupun ikut andil dalam 
pemilihan legislatif di Palestina (Adam, 2016).

Potret hubungan komunis dengan Islam sudah terjadi ketika Perang Dingin. Tulus Warsito berpendapat bahwa keduanya mengalami pengalaman fenomena sosiologi yang sama. Hal ini dibuktikan dengan sebagian besar negara Islam yang mendukung sosialisme pada saat Perang Dingin. Keduanya saling bahumembahu dalam melawan kapitalisme (Warsito, 2019). Atas dasar itu, tidak mengherankan jika kini kita melihat Rusia dengan Sosialisnya berada pada satu barisan dengan Turki di bawah kepemimpinan Erdogan dengan islamnya dalam mendukung eksistensi dari Nicolas Maduro sebagai pemimpin Venezuela.

Bahkan Vladimir Efanov berpendapat bahwa jauh sebelum Perang Dingin Islam sudah mendapatkan tempat di Rusia. Sejak revolusi Sosialis Rusia pada bulan oktober 1917, Rusia membebaskan seluruh rakyat Rusia, termsuk kaum muslimin dari kekuasaan otokrasi Tsar serta menjamin kebebasan mereka termasuk beribadah, berpendapat serta menerbitkan buku-buku agama. Pernyataan tersebut termaktub dalam "deklarasi tentang hak-hak rakyat Rusia" pada tanggal 15 November 1917 yang berisi empat poin utama, yaitu : pertama, persamaan derajat dan kedaulatan rakyat Rusia. Kedua, hak rakyat Rusia untuk menentukan nasib sendiri secara bebas, termasuk memisahkan diri dan pembentukan negara bebas. Ketiga, penghapusan semua dan setiap hak-hak istimewa dan pembatasan-pembatasan nasional dan keagamaan nasional.

Keempat, perkembangan minoritas-minoritas nasional dan golongan-golongan bangsa yang mendiami Rusia secara bebas. Sebulan kemudian pemerintah Soviet mengeluarkan seruan "Kepada semua rakyat pekerja muslimin Rusia dan Timur", yang kurang lebih bunyinya sebagai berikut (Efanov, 2017):

“..... Kaum Muslimin Rusia. Mulai dari sekarang, kepercayaan dan kebiasaan saudara-saudara, institusiinstiutsi nasional, dan kebudayaan saudara-saudara dinyatakan bebas dan tidak dapat dilanggar. Aturlah kehidupan nasional saudara-saudara secara bebas dan tanpa rintangan. Saudara-saudara mempunyai bak untuk. itu. Ketebuilah, bahwa bak-bak. saudara-saudara, seperti balnya dengan hak-hak semua rakyat Rusia, dijamin oleh kekuasaan besar revolusi dan badan-badannya Soviet Perutusan Kaum Buruh, Prajurit, dan Petani."

Hal ini membuktikan bahwa komunis dan Islam memiliki sejarah relasi dalam konteks kaitannya dengan anti kapitalisme (barat). Sehingga sangat rasional melihat hubungan negara komunis saat ini dengan negara berbasis agama Islam 
dalam melawan barat khususnya Amerika yang memiliki sejarah rivalitas panjang dengan keduanya pada masa Perang Dingin dan pasca Perang Dingin.

\section{Aliansi Negara Komunis dan Fundamentalis Agama dalam melindungi Posisi Nicolas Maduro dari Tekanan Negara Barat}

Pada pembahasan sebelumnya penulis menyajikan beberapa data terkait tekanan yang diberikan negara barat kepada Nicolas Maduro serta bagaimana Negara Komunis dalam konteks ini Rusia dan Fundamentalis Agama (Islam) memiliki sejarah tentang hubungan baik mereka. Pada bagian ini penulis ingin lebih fokus kepada bagaimana pada akhirnya Rusia sebagai representasi dari negara komunis dan Turki dari Islam bahumembahu melindungi kepentingan Nicolas Maduro di Venezuela.

Sebagaimana diketahui bahwa baik Putin dan Erdogan telah sama menyampaikan dukungannya kepada Nicolas Maduro. Rusia dan Venezuela bersepakat untuk melanjutkan kerjasama di antara keduanya. Sedangkan Turki melalui Erdogan lebih kepada dukungan Moril (Perdana, 2019). Hal tersebut terjadi di tengah-tengah ketegangan akibat dalam waktu yang hampir bersamaan pemimpin oposisi Juan Guaido mengklaim dirinya sebagai presiden sementara, bahkan posisinya didukung oleh Donald Trump dan beberapa pemimpin negara di kawasan Amerika Latin. Hubungan Rusia dan Venezuela memberikan keuntungan kepada kedua belah pihak. Bagi Rusia, kerjasama dengan Venezuela memberikan ruang untuk memudahkan urusan geopolitik Rusia di kawasan Amerika Latin. Sedangkan bagi Venezuela kesepakatan pasokan senjata memberikan dukungan yang kuat bagi legitimasi militernya (O’Brien, 2019). Menurut laporan Congressional Research Service (CRS), Sejak tahun 2006 Venezuela telah menjadi pusat market bagi senjata Rusia. Sekitar tahun 2006 sampai 2013 saja diperkirakan telah terjadi transaksi hingga 4 milyar dolar Amerika, meskipun sebagian besar berupa kredit. Perusahaan minyak Rosneft asal Rusia hingga berani berinfestasi hingga 3 milyar dolar Amerika (Service, 2019). Dengan melihat kepentingan yang didapatkan keduanya, tentu Rusia akan dengan suka rela mendukung posisi Maduro sebagai presiden Venezuela yang sah. Lalu bagaimanakah upaya Putin melindungi posisi Maduro?

Menurut The New York Times kementerian keuangan Rusia telah bersedia memberikan bantuan pinjaman sebesar 3,1 milyar dolar untuk pembelian senjata, truk dan beberapa alat lainnya untuk 
memperkuat persenjataan militer Venezuela (The New York Times, 2019). Kekuatan militer adalah satu-satunya kekuatan terpenting bagi Nicolas Maduro, paling tidak pada saat ini dan dalam kondisi seperti ini. Hal ini menjadi upaya pemerintah untuk mempertahankan kekuasaannya dari desakan pihak oposisi dan masyarakat internasional yang mulai memberikan ancaman bagi pemerintahan Maduro.

Komitmen Rusia untuk membantu Venezuela sudah tidak perlu ditanyakan lagi. Sekitar tahun 2016 lalu, Putin telah memantapkan diri untuk komitmen membantu Venezuela melalui Sechin dan Rosneft, dengan cara membuat Maduro dan PDVSA bertahan dengan pinjamanpinjaman yang dijamin oleh minyak Venezuela (Negroponte, 2018). Segala upaya telah dilakukan oleh Rusia demi membantu mempertahankan eksistensi Presiden Nicolas Maduro dengan segala pertimbangan dan kepentingan yang sudah dijelaskan di atas.

Turki secara histori tidak memiliki hubungan yang spesial dengan Venezuela, namun beberapa tahun terakhir Turki di bawah pemerintahan Erdogan menjadi sangat aktif dalam membangun relasi baik di bidang politik maupun ekonomi. Irmak Ekin Karel menerangkan bahwa pertemuan pertama antara keduanya dimulai sejak tahun 2016, tepat setelah satu bulan kegagalan upaya kudeta kepada Presiden Erdogan di Turki. Hasil dari kerjasama tersebut adalah meningkatnya volume perdagangan dari 82 juta dollar Amerika di tahun 2016 menjadi 1,1 milyar dolar Amerika di tahun 2018 (Karel, 2019).

Selain itu, pertumbuhan ekonomi Turki yang signifika di abad 21 ini memberikan kekuatan untuk menandingi hegemoni Amerika termasuk juga menjaga hubungan dengan Rusia, Iran termasuk juga dengan Venezuela. Posisi Turki tersebut kerap kali menjadi tantangan eksistensi barat dalam mendominasi tatanan internasional, termasuk juga upaya Turki dalam membangun aliansi baru (Karel, 2019). Dengan demikian kita bisa simpulkan bahwa tulisan ini merupakan upaya aliansi dari ketiga negara yakni Rusia, Turki dan Venezuela dalam memberikan tandingan bagi eksistensi negara barat yang dipelopori Amerika.

\section{KESIMPULAN}

Setelah menjalani penelitian melalui studi pustaka dan menyusun analisa dengan sedemikian rupa, akhirnya penulis sampai juga pada bab terakhir di tulisan ini.

Hubungan antara negara komunis dalam hal ini Rusia dan negara fundamentalis dalam konteks ini Turki di bawah rezim Erdogan 
telah memberikan gambaran dari balance of power di abad 21, di mana setelah runtuhnya Rusia pasca Perang Dingin dan menjadikan Amerika sebagai satu-satunya negara adidaya, kali ini memiliki penantang baru yakni tidak hanya dari negara Komunis tetapi juga dari Negara Fundamentalis. Hal tersebut tergambar dalam kasus Venezuela yang notabene menjadi sekutu bagi Rusia dan Turki telah didukung habis-habisan untuk mempertahankan posisi pemimpinnya Nicolas Maduro yang terancam digulingkan oleh masyarakat yang melakukan protes di bawah komando Guaido. Adapun bentuk dukungan Rusia adalah dari bantuan dana dan militer untuk memperkuat barisan militer Venezuela melihat bahwa keduanya memiliki ideologi yang sama komunis. Ini merupakan salah satu hal yang paling dibutuhkan Maduro untuk mempertahankan kekuasaannya. Sedangkan Turki lebih banyak melakukan dukungan secara moral dan ekonomi di mana hubungan mereka sudah terjalin erat sejak tahun 2016

Penelitian ini tidak cukup ruang untuk menjelaskan secara gamblang apa saja yang terjadi di Venezuela. Penulis pun mengakui memiliki keterbatasan dalam mengkaji fenomena tersebut. Sehingga tulisan ini hanya berfokus pada bagaimana ketiga negara tersebut beraliansi yang diawali dengan gambaran singkat tentang kondisi
Venezuela serta tekanan apa saja yang diterima oleh Nicolas Maduro dari pihak oposisi dan internasional. Penulis berharap bahwa tulisan selanjutnya dapat lebih luas menjelaskan bagaimana kepentingan Amerika di wilayah Amerika Latin sehingga bersifat sangat represif terhadap pemerintahan Maduro. Selain itu, akan sangat baik jika selanjutnya dapat mengkaji tentang sejauhmana Maduro dapat bertahan dari tekanan oposisi dan internasional meskipun telah mendapat dukungan dari Rusia dan Turki.

\section{DAFTAR PUSTAKA}

Adam, A. (2016) Kisah Partai-Partai Komunis Palestina Melawan Israel (Online). Available at: https://tirto.id/kisahpartai-partai-komunis-palestinamelawan-israel-b5Ax (Accessed: 2 Agustus 2019).

BBC Indonesia. (2019) Bagaimana Krisis Dalam Negeri Venezuela dapat Menjadi Masalab Global (Online). Available at: https://www.bbc.com/indonesia/duni a-47000419 (Accessed: 23 Juli 23, 2019).

CNN Indonesia. (2019) Trump Akui Juan Guaido Jadi Presiden Sementara Venezuela (Online). Available at: https://www.cnnindonesia.com/intern asional/20190124021515-134363314/trump-akui-juan-guaido-jadipresiden-sementara-venezuela (Accessed: 28 Februari 2019).

Efanov, V. (2017) Islam di Negara Komunis: Kebijakan Uni Soviet Terbadap Kaum Beragama. Yogyakarta: Oktober Light 1917. 
Firdaus, F. (2018) "Strategi Perlawanan Venezuela dalam Menghadapi Tekanan Amerika Serikat melalui ALBA Tahun 2015-2017." Jurnal Fisip Universitas Airlangga, Vol. 1.

John L.Esposito, M. A.-J. (2010) Dialektika Peradaban. Modernisme Politik dan Budaya di Akhir Abad ke-20. Yogyakarta: Qalam.

Jusuf, W. (2017) Setelah Melintasi Abad 19 dan 20, Apa Lagi dari Komunisme? (Online). Available at: https:/ / tirto.id/setelahmelintasi-abad-19-dan-20-apa-lagi-darikomunisme-cxyY (Accessed: 2 Agustus 2019).

Karel, I. E. (2019 "Turkish foreign policy in Venezuela: What factors can explain Turkey's sudden and accelerated rapprochement with Venezuela in the last years?" Revista, 92(1), p. 3.

Kurmanaev, Anatoly. (2019) Why Is Russia Helping Venezuela? (Online). Available at:

https://www.nytimes.com/2019/03/0

8/world/americas/russia-venezuelamaduro-putin.html (Accessed: 29 November 2019).

Michael Roskin, N. B. (1990) IR: An Introduction to International Relations. New Jersey: Prentice Hall.

Mudzakkir, A. (2016, Juni) "Islam dan Politik Di Era Kontemporer”, Epistemé, Vol. 11, No. 1, p. 32.

Negroponte, D. V. (2018) Politics, Business \& Culture in the Americas (Online).

Available at: https://www.americasquarterly.org/co ntent/russian-interests-venezuela-newcold-war (Accessed: 3 November 2019).

O’Brien, A. (2019) "Venezuela and Russia: Geopolitical Allies in the 21st Century," The Yale Review of International Studies.

Perdana, A. V. (2019) Putin dan Erdogan Menyatakan Dukungan terhadap Presiden Maduro (Online). Available at: https://internasional.kompas.com/read /2019/01/25/13573451/putin-danerdogan-menyatakan-dukunganterhadap-presiden-maduro?page $=$ all (Accessed: 6 November 2019).

Riza, B. (2019) Cina, Rusia, Turki Dukung Maduro, 3 Alasannya? (Online). Available at: https://dunia.tempo.co/read/1170770 / cina-rusia-turki-dukung-maduro-3alasannya (Accessed: 28 Februari 2019).

Rofii, M. S. (2019) Islam di Langit Turki. Ygyakarta: IRCiSoD.

Romero, C., \& Mujares, V. (2016) "From Chavez to Maduro: Continuity and Change in Venezuelan Foreign Policy." Contexto Internacional, Vol. 38(1), pp. 165-201.

Seelke, C. R., Brown, P., M. Nelson, R., \& Margesson, R. (2019) "Venezuela: Background and U.S. Relations". Congressional Research Service, No. 9.

Service, C. R. (2019) Venezuela: Background and U.S. Relations. CRS Report, No. 21.

Vitria, V. (2009) "Konflik Peradaban Samuel P. Huntington(Kebangkitan Islam yang Dirisaukan?)". Humanika, Vol. 9, No 1, p. 40.

Walt, S. M. (1985) "Alliance Formation and the Balance of World Power", International Security, Vol. 9 No. 4, pp. 343.

Warsito, T. (2019) "Krisis Arab dan Masa Depan Dunia Islam", Interviewed by Nuswantoro, B.S. Yogyakarta.

Wendt, A., Levy, J. S., \& Little, R. (2014) Metodologi Ilmu Hubungan Internasional; Pendekatan Paradigmatik dan Pendekatan Alternatif. Malang: Intrans Publishing.

Yuniarti. (2010) Perubahan Pola Hubungan Internasional Abad 20 dan Pengaruhnya Terhadap Realisme Versus Idealisme. Jurnal Sosial Politika, 2, Vol. 17, pp. 41-53. 